\title{
Fine-Grainedcellular Concrete Creep Analysis Technique with Consideration Forcarbonation
}

\author{
Said-Alvi Yusupovich Murtazaiev ${ }^{1}$, Valeriy Stanislavovich Lesovik ${ }^{2}$, Deni Karim-Sultanovich Bataiev ${ }^{3}$, Natalia \\ Vasilievna Chernysheva ${ }^{4} \&$ Magomed Salamuvich Saidumov $^{5}$ \\ ${ }^{1,5}$ Groznenskiy State Oil Technical University n.a. Member of the Academy Millionshtchikov, M. D., Grozny, \\ Chechen Republic, Russia \\ ${ }^{2,4}$ Belgorodskiy State Technological University n.a. Shukhov, V. G., Russian Federation, Belgorod, Russia \\ ${ }^{3}$ Complex Research and Development Institution n.a. Ibragimov, H. of the Russian Academy of Sciences, \\ Russian Federation, Grozny, Chechen Republic, Russia
}

Correspondence: Saidumov Magomed Salamuvich, Groznenskiy State Oil Technical University n.a. Member of the Academy Millionshtchikov, M. D., Russia, Grozny, Chechen Republic, Russia. E-mail: saidumov_m@mail.ru

Received: November 9, 2014

Accepted: November 13, $2014 \quad$ Online Published: March 4, 2015

doi:10.5539/mas.v9n4p233

URL: http://dx.doi.org/10.5539/mas.v9n4p233

\begin{abstract}
The article is devoted to the problems of improving efficiency and cost reduction of fine-grain concrete at production of small wall products by complex use of fabricated raw materials in the form of TPP bottom-ash mixtures. The results of bottom-ash mixtures research and composite gypsum binders (CGB) for fine-grain concrete based on such mixtures are provided in the paper. Microstructure and morphology of fine mineral additives of slag and fly ash and prospects of using these components as filler in CGB composition are researched. The properties of fine-grain concrete and concrete mixtures on this CGB are researched: workability, porosity, density, strength, and deformation properties. Experimentally proven is the effectiveness of integrated use of local raw materials, including fabricated materials, in the production of CGB and fine-grain concrete based on it.
\end{abstract}

Keywords: fabricated raw materials, ecology of a city, bottom-ash mixture, filler of bottom-ash mixtures, composite gypsum binder, fine-grain concrete, small wall products, environmental and economic effects

\section{Introduction}

Currently the fastest growing rates of construction in some regions of the country, including Chechnya, claim for a significant increase in production of high quality construction composite materials, which manufacturing and processing requires less possible amount of energy and investment. The necessity to develop and implement effective production, including the so-called "green composites", is also claimed by the modern requirements and resource and energy saving in construction and energy efficiency of building production.

One of such materials that meet the requirements of resource and energy saving at their production, of heat protection and environmental safety are gypsum binders and products based on them, as the most efficient in terms of energy intensity of production and the negative impact on the environment. Their hardening occurs rapidly without heat and humidity treatment (Chernysheva et al., 2011).

The most promising solution to this problem, in accordance with modern international standards of "green building" and "green composites", is the integrated use of available, cheap, often untapped local raw materials, which, in addition to natural resources and secondary resources, are of fabricated origin.

In Chechen Republic, having large reserves of natural raw materials for production of cement, gypsum binders, fine and coarse aggregate concrete and fabricated raw materials in the form of multi-tonnage bottom-ash mixtures (BAM), concrete scrap and other wastes of building demolition, production of high quality building materials with complex use of local raw materials, can make a significant contribution to the further formation of the construction industry and ensure environment protection (Alaskhanov, 2013).

In addition, currently there is a need in the region in many building materials, particularly in wall materials. The 
rational use of the available mineral and raw materials base based on advanced technologies can result in competitive construction products not inferior to foreign analogues. This fully applies to the preparation of composite gypsum binders (CGB) with BAM filler and wall products based on them, allowing significant reduction of shortage of building materials used for repair and restoration of old, ruined buildings and construction of new facilities.

This scientific direction on the development of effective composite building materials using recycled materials is very important for the whole country, as, currently mining, metallurgical, chemical, wood, energy, building materials and other production industries of the Russian Federation annually produce more than 7 billion tonnes of wastes. Only about 2 billion tonnes or $28 \%$ of the total volume are re-used. In this regard, dumps and sludge ponds of the country have accumulated more than 80 billion solid wastes only. Fields for their storage annually alienate about 10 thousand Ha of agriculture-suiTable land (Dvorkin, 2007).

\section{Literature Review}

A promising direction for development of building materials industry is development of non-waste technology of construction composites manufactured based on gypsum binders that meet all modern requirements for fire resistance, sound absorption, environmental assessment norms of the International standards, taking into account all stages of the product life cycle, starting from the extraction of raw materials and up to disposal, according to hygienic requirements and the degree of safety for human health (Gusev \& Dementiev, 1999; Ursu \& Dorozhkin 2007; Hanna et al., 2000). Preparation of water-resistant gypsum-containing binders with rapid-integrated use of fabricated materials will significantly increase turnover forms, production efficiency of products based on them, simplify the technology, giving the possibility to get rid of heat treatment of products and reduce the cost of finished products.

Many Russian and foreign researchers have been engaged into finding the solution to improve the water resistance of gypsum and increased mechanical strength, these are: A. A., Bozhenov, P. I., Budnikov, P. P., Bulychev, G. G., Volzhenskiy, A. V., Kopelyanskiy, G. D., Ferronskaya, A. V., Stambulko, V. I., Korovyakov, V. F., Baldin, V. P. Baldin et al. Application of gypsum materials and products is limited to a relative humidity of $60-75 \%$ in the premises. Therefore, many researchers are working to improve water resistance of gypsum binder and gypsum products (Alhaj Hussein, 2010; Strokova et al., 2013; Korovyakov, 2005).

According Budnikov, P. P. et al., the main cause of poor water resistance of gypsum products is relatively high solubility of gypsum comprising $2.04 \mathrm{~g} / 1$ of $\mathrm{CaSO} 4$ at $20^{\circ} \mathrm{C}$. When moisture gets into pores of the products, due to dissolution of dihydrate crystals, saturated solution of calcium sulphate formates, thereby weakening connection between crystals and products' strength is reduced (Budnikov, 1951).

Rebinder, P. A., and some other scientists believe that the reason for strength decrease of hardened gypsum binder at moisturizing is adsorption of moisture by inner surfaces of the microcracks and thus occurring wedging action of water films, in which some microelements of crystal structure are disconnected. At that, porosity exacerbates the adsorption effect of gypsum materials.

Low water resistance of gypsum binder is due to the high solubility of calcium sulphate dihydrate, its high permeability, and wedging action of water molecules at intercrystalline cavities penetration. Hardened gypsum binder structure is characterized by highly interconnected porosity with pore size ranging between 1.5-3.0 microns, elongated calcium sulphate dihydrate crystals having point interconnections tending to rupture at low strength. Moreover, calcium sulphate dihydrate is characterized by rather large volume of interplanar (intercrystalline) spaces (cavities), where water gets loosening connections and dissolving gypsum (Ferronskaya, 2004).

There are numerous ways to improve water resistance of gypsum: improving water resistance is achieved by reducing water solubility of calcium sulphate, gypsum mass compaction, impregnating substances that prevent moisture penetration.

In recent years, some researchers are attracted by the hypothesis that the interaction of different binders with water, especially multimineral binders, in real conditions occurs concurrently on a mixed pattern: according to Le Chatelier, A. - with dissolution of the substance in water, followed by hydration and its transition into the sediment hydrate. In addition, it can happen topochemically, according to Baikov, A. A. - by direct addition of water to the solid phase.

Currently it is proved that one of the main ways of improving water resistance of gypsum binder is adding agents entering chemical reaction with it to form water-resistant and water-curing products because of chemical reaction with gypsum binder, and because of their own hydration. Such materials are portland cement and ground 
granulated blast furnace slag, use of which is noted in papers (Lesovik et al., 2011). Use of portland cement as an additive to gypsum often led to inconsistent results. In some cases, water resistance and strength increased in the initial period of hardening, in other cases, at increasing water resistance, samples, having sufficient mechanical strength at the beginning, were destroyed in 30-40 days.

One of the ways to increase water resistance of gypsum binders is to provide gypsum-cement-pozzolanic binders (GCPB), and development of GCPB technology.

The most sustainable and effective compositions are the new generation of composite gypsum binders with low water requirement (CGB) proposed and thoroughly studied in MICE n.a. Kuybyshev, V. V. (now MSCU) and in other organizations by Volzhenskiy, A. V., Stambulko, V. I., Ferronskaya, A. V., Korovyakov, V. F. et al. based on application of nanotechnology and physicochemical mechanics in the field of building materials, including binders. These compositions consist of a gypsum binder, a proper amount of portland cement, and the required quantity of pozzolanic hydraulic additives comprising of silica in active form and capable of hardening without destructive deformation in moist and aqueous environments at the same setting speed as in hemihydrate gypsum binder. Unlike portland cement, products of these binders, in many cases do not require heat and humidity treatment as already after 2-4 hours after production, they gain of 30-40\% of final strength (Vozhenskiy, 1986; Ferronskaya et al., 1988; Shukla et al., 2005).

Korovyakov, V. F. developed a scientific concept (Korovyakov, 2005), according to which CGB shall be a homogeneous mixture of dispersed components, one of which must serve as the controlled early setting for rapid strength development (this may be one or a combination of modifications of gypsum binders). Another or other shall ensure hydraulic qualities of binder and further growth of strength due to the formation of a new type of structure, helping to improve durability and other properties of the resulting stone (these may be portland cement or lime, together with silica mineral components of optimum dispersion). Third - modifying additives - are designed for sharp decline in water demand of binders, contributing to its more complete and more rapid hydration, ensuring convergence of dislocations, thereby increasing the number of contacts between the particles, regulating other properties in the right direction (these can be plasticizing agents, regulators for setting and hardening, as well as polymer additives) (Ferronskaya and Korovyakov., 1998; Korovyakov, 2013 p.15-17; Korovyakov, 2013 p.17-19).

Based on modern concepts of gypsum cement-silica systems hardening mechanisms, it can be said that ensuring their durability shall be made through observing the following conditions: providing binding of the majority of aluminates with gypsum to form ettringite in the initial period of system's hardening while increasing the degree of portland cement hydration level by, for example, mechanochemical activation (Kazili $u$ nas and Ba with Auskien, 2007; Wolicka, 2008); maintaining calcium hydroxide concentration at the desired level during the curing conditions for the formation of different hydrated newgrowths, including low-basic calcium hydroaluminates. For this purpose, the amount of siliceous additives shall correlate with the amount of portland cement and mineral composition, and binding of calcium hydroxide with silica additives shall occur in the initial period of structure formation and during prolonged hardening. This can be achieved by using both highly active wastes of various industries (silica fume, fly ash, slag, etc.) and low active wastes (ceramic dust from fine-grain silica sand, cullet, etc.) in combination with active wastes (Kolesnikova, 2002 ; Belov and Smirnov, 2009).

Another well-known water-resistant gypsum binder is gypsum-lime-slag binder (GLSB), developed in Ural Polytechnic Institute, and implemented at Krasnoufimskaya factory of building materials. The designed binders, unlike non-water-resistant gypsum binders, have universal properties, manifested in the ability to hydraulic hardening, less prone to creeping and sufficient durability (Burnett and Elzerman, 2001; Perianez, 2005; Pereira, 2003).

However, despite the high technical and economic efficiency of construction materials made of such binders, their use in construction at present insufficient. Therefore, improving the efficiency of gypsum binders and concretes based on them, aimed at improving and perfecting technological, functional, operational properties, and expanding the scope of gypsum binders is an urgent problem.

Thus, the analysis of domestic and foreign applications of gypsum-containing composites in construction demonstrated that the materials and products based on them are the most relevant to the requirements of modern architecture and construction practice. The decisive factor is the quality and cost of the material, the rate of construction of facilities, expansion of architectural and building solutions based on the use of fast hardening concretes with improved strength and deformation characteristics.

For a number of regions, including Chechen Republic, the widespread use of gypsum binders in the construction and decoration of buildings and structures is of particular significance: there are large reserves of explored 
gypsum deposits; use of materials based on gypsum binders provides a more comforTable environment for human stay indoors in different climatic zones with a large range of temperature and humidity parameters; production time of works using concrete and mortar based on gypsum binders is several times lower than with similar materials based on portland cement, and others.

Therefore, the most important area of research in building materials is to improve the production technology of gypsum-containing composites, improve their performance and operational characteristics that will contribute to the development of "green building" and production of "green" high-performance building materials.

\section{Methodology}

In this regard, the Scientific and Technical Centre for collective use of Grozny State Oil Technical University n. a. the Member of the Academy Millionshtchikov, M. D. and Belgorod State Technological University n.a. Shukhov, V. G. are conducting the comprehensive research to address the actual problem for formulating the composite gypsum-containing binders and concrete based on it using fabricated and natural substandard raw materials.

Research and analysis of the materials' properties (fly ash and slag) and gypsum-containing composites derived from them were carried out by using both precision tool methods of research - such as XRF, SEM, and SORBI-M (a device intended for measuring the specific surface of dispersed and porous materials), and standard methods for determining properties of raw materials, mixtures, and hardened composites based on CGB.

Research of effects of composite gypsum binders, active mineral additives types, and chemical additives on the properties of hardened concrete mixtures and gypsum-containing composites was made using complex research methods regulated by the state standards.

The research methods used in the framework of the scientific work are based on the known provisions of the theory for hardening of clinker minerals with fillers of different composition, in particular, bottom-ash mixtures (BAM), mathematical logic, technology of composite materials, the theory of automation and control of technological processes and manufactures.

According to the results of preliminary tests with allowance for inhomogeneous composition and characteristics of fabricated raw materials processing, it was found that one of the ways of rational use of secondary resources is adding them to fine-grain concrete composition as fine-grain filler with chemical modifiers.

Initial materials for production of fine-grained concrete for small piece wall products include BAM used as active mineral supplement, portland cement of CEM I 42,5N grade from Chiri-Yurtovskiy cement plant, such chemical additives as Polyplast SP-1 superplasticiser, and citric acid, gypsum binder of $\beta$-modification of G5B II grade by Astrakhan gypsum plant, and such sands as slag sands from Grozny TPP refuse bank; and quartz sands from Chervlenskoye field.

\section{Results}

Studies of BAM properties (Table 1) added to gypsum cement compositions for controlling hardening process and helping changing the final properties of the materials showed that their hydraulic activity is the most important property determining the possibility of their use in binders and concretes based on them. At that, increase in the specific BAM surface area increases the reactivity of their minerals, contributing to removing conditions of formation and accumulation of ettringite due to binding silica-activated calcium hydroxide and reducing the amount of aluminate components due to accelerated hydration of portland cement. This causes an increase in strength and durability of the formed structure of hardened gypsum-containing binders filled with bottom ash and concretes based on them.

Table 1. Indices of fine-grain mineral additives properties

\begin{tabular}{lcc}
\hline \multicolumn{1}{c}{ Index } & \multicolumn{2}{c}{ Fine-grain mineral additive of } \\
\cline { 2 - 3 } & fly ash & slag \\
\hline Specific surface area $\mathrm{m}^{2} / \mathrm{kg}$ & $600-690$ & $450-500$ \\
Pores volume with $\mathrm{R}<19.4 \mathrm{~nm}, \mathrm{~cm}^{3} / \mathrm{kg}$ & 18 & 3 \\
Grinding time, minutes & $5-10$ & $5-10$ \\
\hline
\end{tabular}

It is established that slag (fly ash) contains, \%: $\mathrm{SiO}_{2}-67.46$ (52.44); $\mathrm{Al}_{2} \mathrm{O}_{3}-15.05$ (5.57); $\mathrm{Fe}_{2} \mathrm{O}_{3}-2.65$ (11.37); $\mathrm{TiO}_{2}-0.36$ (0.28); $\mathrm{MgO}-0.54$ (2.35); $\mathrm{CaO}-5.45$ (19.8); $\mathrm{K}_{2} \mathrm{O}-5.16$ (2.02); $\mathrm{Na}_{2} \mathrm{O}-2.59$ (0.86); $\mathrm{SO}_{3}-0.24$ 
(1.28).

BAM-based mineral additives chemical composition analysis demonstrates that they contain $\mathrm{SiO}_{2}$ and $\mathrm{Al}_{2} \mathrm{O}_{3}$, which at normal temperatures in particulate form capable of binding calcium hydroxide to form insoluble compounds, i.e. have pozzolanic activity and therefore may be used as active mineral additives in CGB production.

In addition, it is found that the composition of ash and slag products has prevailing clay calcinates: amorphised clay matter of metakaolinite type, amorphous $\mathrm{SiO}_{2}$ and $\mathrm{Al}_{2} \mathrm{O}_{3}$, aluminosilicate glass (6).

More acidic mineral additives having basicity module $M_{O}<1$ have increased activity, which can be seen from the alumina modulus $p$ and the activity modulus $M a$ (Table 2). BAM hydraulic activity increases with increasing values of these moduli. At that, the higher the activity modulus is the faster BAM hardening in the milled condition is.

Table 2. TPP BAM characteristics comparison

\begin{tabular}{lll}
\hline \multirow{2}{*}{ Modulus name } & \multicolumn{2}{c}{ Index value, $\%$} \\
& in slag & in fly ash \\
\hline Alumina modulus, $p=\mathrm{Al}_{2} \mathrm{O}_{3} / \mathrm{Fe}_{2} \mathrm{O}_{3}$ & 5.68 & 0.50 \\
Basicity factor, $M_{\mathrm{O}}=\mathrm{CaO}+\mathrm{MgO} / \mathrm{SiO}_{2}+\mathrm{Al}_{2} \mathrm{O}_{3}$ & 0.07 & 0.38 \\
Activity modulus, $M a=\mathrm{Al}_{2} \mathrm{O}_{3} / \mathrm{SiO}_{2}$ & 0.22 & 0.11 \\
\hline
\end{tabular}

The obtained results are confirmed by experimental data of mineral additives heat radiation kinetics. Fly ash and slag heat radiation kinetics from the moment of their mixing with mixing water was researched. The research used differential quasiisothermal calorimeter with computer processing (Figure 1).

It was established that the heat radiation of fly ash and slag differs in intensity and duration. After 100 seconds after contact with water, heat radiation rate of fly ash reaches a maximum value of $0.03 \mathrm{~kW} / \mathrm{kg}$, and is distinct for stretch and delayed start reaction with water (in 10 seconds). Slag exhibits significantly faster reactivity (1-2 seconds) and in 10-15 seconds, its heat radiation reaches its maximum value of $0.02 \mathrm{~kW} / \mathrm{kg}$. The peculiarity of the provided thermograms is in the fact that the intensity level of fly ash residual heat radiation during induction period in 200-500 seconds after mixing with water reduces by only $25 \%$ (0.02 units), while slag demonstrates acute slump in 15-20 seconds and heat radiation is almost complete after 50 seconds. This phenomenon can be explained by the fact that in aqueous environment, slag grains surface has a large number of active centres of various nature acting as a finished substrate for creation of hydrated compounds nucleates.

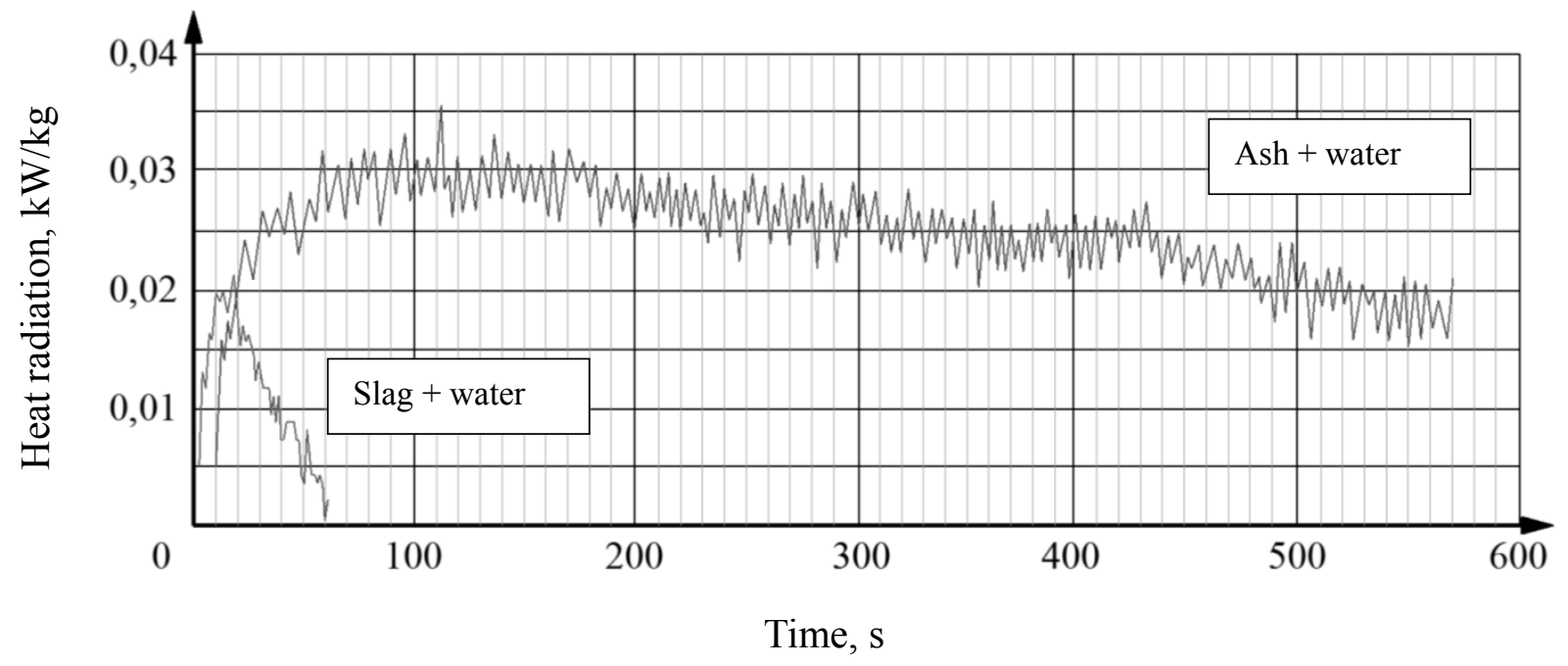

Figure 1. Systems thermograms: a) ash + water; b) slag + water

Analysis of microstructure and morphology of Grozny TPP fly ash and slag fine-grain mineral additives showed that their particle shape varies depending on the size. Slag particles consist primarily of dense glassy particles of varying size of cubic and rounded shapes with layered structure (Figure 2a). 
The biggest part of ash dust consists of porous glassy particles of different size of plate, irregular, and angular shape. The distinguishing feature is presence in the mixture of porous particles with relatively large concave surface and fine-grain particles of flocculated structure (Figure 2b).

It shall be also noted that mineralogical composition of the fly ash will vary depending on the grade, dispersion of pulverized coal, combustion modes and other factors.

TPP fly ash crystalline component, as shown by the results of XRF, consists of two modifications of quartz, magnetite, $\mathrm{Fe}_{3} \mathrm{O}_{4}$, calcite $\mathrm{CaCO}_{3}$, and calcium-ferrous silicate $\mathrm{SaFeSi}_{2} \mathrm{O}_{6}$.

Slag mainly contain (95\%) glass phase due to the increase in duration of slag exposition to high temperatures zone. Crystalline phase is represented by albite, NaAl-silicates, and Al-silicates, several different modifications of quartz $\left(\mathrm{SiO}_{2}\right)$, differing from natural modification by the parameters of crystalline grid, which is connected with its fabricated origin.

Since durability of gypsum cement systems (gypsum + cement + additive + water) depends on the correct balance between the amount of portland cement and siliceous additive, the authors found the influence of dispersion and the ratio of components in the properties of CGB and hardened stone structure (cement + gypsum + additive).

The curves of granulometric composition of slag and fly ash with a specific surface of 470 and $690 \mathrm{~m}^{2} / \mathrm{kg}$, respectively, showed that the primary fly ash particle size range, which covers more than $90 \%$ of the material, is limited to fractions of (18.15-201 microns); and slag particles is limited to fraction of (1.1-60.35 microns).

The effectiveness of the researched additives witnesses the reduction of calcium oxide concentration in solution: for fly ash after 5 days up to $1.23-0.86 \mathrm{~g} / \mathrm{l}$, on the 7th day up to 1.18-0.84 $\mathrm{g} / \mathrm{l}$, with obligatory ratio of mineral additives (A), and cement (C) $\mathrm{A} / \mathrm{C}=1: 1.5$; for slag after 5 days up to $0.22-0.14 \mathrm{~g} / \mathrm{l}$, on the 7 th day up to $0.15-0.13 \mathrm{~g} / \mathrm{l}$ with obligatory ratio $\mathrm{A} / \mathrm{C}=1: 0.5$. The resulting relationship between $\mathrm{A} / \mathrm{C}$ serves as the basis for calculation of CGB formulation (9), which was adopted as follows. In the resulting two CGB formulations, gypsum part was $70 \%$ by weight, and the remaining $30 \%$ included Portland cement + mineral additive. In CGB based on slag mineral additive, amount of the latter was $10 \%$ in CGB based on fly ash - $18 \%$ of ash filler.

\section{5,000 times increase}
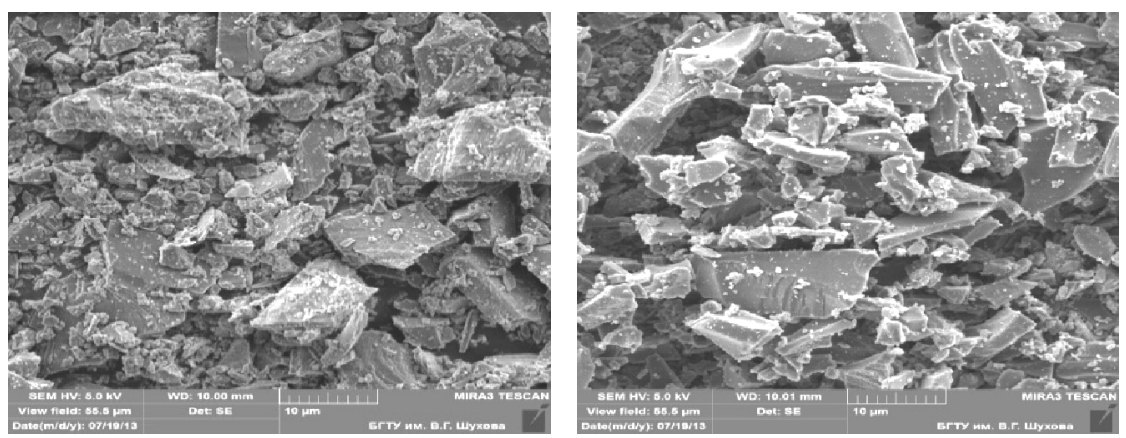

50,000 times increase

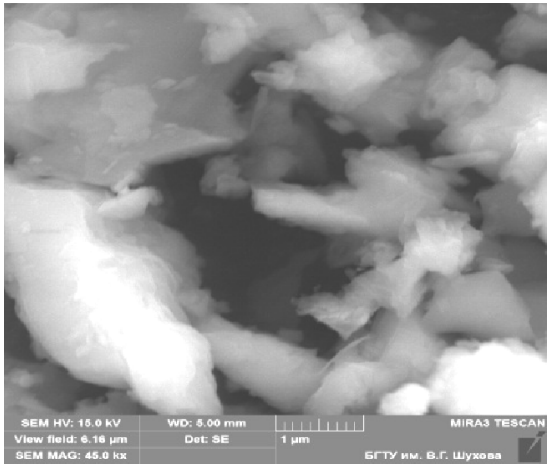

a

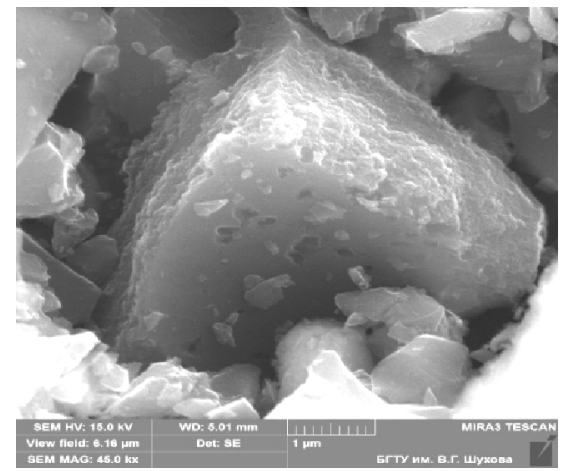

$b$

Figure 2. Microstructure and morphology of fine-grain mineral additives of slag (a) and fly ash (b) 
It is established that with the decrease in calcium hydroxide concentration, highly basic conditions for the formation of ettringite and calcium hydroaluminate disappear. The cavities between calcium sulphate dihydrate crystals are filled with the smallest newgrowths' particles and ultrafine-grain portland cement and active mineral additive particles that increase the contact between crystals and density, strength, water resistance, and durability in general of the hardened binder, which is confirmed by complex researches of its phase composition, hydration processes, and stone structure formation on CGB by electron microscopy and XRF.

In order to improve physico-mechanical parameters of stone on $\mathrm{CGB}$, hemihydrate gypsum $\mathrm{CaSO}_{4} \cdot 0.5 \mathrm{H}_{2} \mathrm{O}$ was added to mixing water in an amount to obtain a saturated solution - up to $7.1 \mathrm{~g} / 1$. At that, it is established that at adding $\mathrm{CaSO}_{4} \cdot 0.5 \mathrm{H}_{2} \mathrm{O}$, test mobility does not change, strength of the hardened stone is increased by $18 \%$ after 2 hours and by $15 \%$ in 28 days; softening coefficient $\mathrm{K}_{\mathrm{R}}$ of hardened composite constituted $0.64-0.69$. It is important to note that adding $\mathrm{CaSO}_{4} \cdot 0.5 \mathrm{H}_{2} \mathrm{O}$ not only increases the final strength of the hardened composite but also increases the setting time of the cement paste from 8 minutes to 11-13 minutes. Mortar mobility by flow was $0.18 \mathrm{~m}$ with respect to water-binding ratio $\mathrm{W} / \mathrm{B}=0.44-0.5$.

As a result of the dissolution, hydrolysis and crystallization in CGB - water, the main component of the pore electrolyte are associated molecules of $\mathrm{CaSO}_{4}$, changing the concentration of which can be used for adjusting both setting time and strength development of the hardened binder.

The authors also studied the effect of chemical additives on CGB properties, because their role for fine-grain multicomponent systems is very important (Table 3).

Table 3. Effect of chemical additives on CGB properties

\begin{tabular}{|c|c|c|c|c|c|c|c|c|}
\hline \multirow{2}{*}{$\begin{array}{l}\mathrm{S} / \\
\mathrm{N}\end{array}$} & \multirow{2}{*}{ Additive type } & \multirow{2}{*}{$\begin{array}{l}\text { Content of } \\
\text { additive, } \\
\% \text { by weight }\end{array}$} & \multirow{2}{*}{$\begin{array}{l}\text { Flow } \\
\mathrm{m}\end{array}$} & \multicolumn{2}{|c|}{$\begin{array}{l}\text { Setting time, } \\
\text { minutes - } \mathrm{s}\end{array}$} & \multicolumn{3}{|c|}{$\begin{array}{l}\text { Strength } \\
\text { of compression, } \mathrm{MPa}\end{array}$} \\
\hline & & & & & end & $2 \mathrm{~h}$ & 7 days & 28 days \\
\hline 1 & No additive & - & 0.120 & $8-00$ & $11-00$ & 3.4 & 13.4 & 14.1 \\
\hline \multirow{4}{*}{2} & \multirow{4}{*}{$\begin{array}{l}\text { Polyplast- } \\
\text { SP-1 }\end{array}$} & 0.1 & 0.160 & $7-45$ & $10-45$ & 5.0 & 14.5 & 15.7 \\
\hline & & 0.3 & 0.180 & $7-30$ & $10-30$ & 4.4 & 13.9 & 14.7 \\
\hline & & 0.5 & 0.220 & $7-15$ & $10-15$ & 4.2 & 13.4 & 13.9 \\
\hline & & 0.03 & 0.160 & $18-45$ & $25-15$ & 4.8 & 9.2 & 10.4 \\
\hline \multirow[t]{2}{*}{3} & Citric acid & 0.05 & 0.162 & $24-30$ & $28-30$ & 4.9 & 9.7 & 11.4 \\
\hline & & 0.07 & 0.162 & $29-30$ & $34-30$ & 5.0 & 10.2 & 11.9 \\
\hline 4 & $\begin{array}{l}\text { Citric acid + Polyplast } \\
\text { SP-1 }\end{array}$ & $0.05+0.3$ & 0.265 & $30-00$ & $35-15$ & 4.3 & 13.2 & 13.8 \\
\hline
\end{tabular}

Fine-grain grinding of binders leads to an increase in their water consumption and flocculation of particles when mixed with water, resulting in significant amount of non-hydrated grains. To reduce CGB water consumption, Polyplast SP-1 superplasticiser was used capable of dispersing hard phase particles, forming solvation shell on them for controlling setting time of binder - citric acid, as well as complex chemical additive (CCA). Surfactants plasticising effect was established on the consistency of the paste at constant water/binder. Additives were added together with the mixing water. Effectiveness of Polyplast-SP-1 (0.1-0.5\%) superplasticiser is confirmed by the increase of mixture mobility (from 0.12 to $0.22 \mathrm{~m}$ ), of citric acid - by reduction of the start of setting from 18-45 to $29-30 \mathrm{~min}$.

The developed CCA (citric acid + Polyplast SP-1) gives the possibility for adjusting the start of setting to 30 minutes and CGB hardening speed.

Creation of small piece wall materials were made by fine-grain concrete compositions of hard and movable mixtures based on the developed CGB on fly ash and slag, used as active mineral additives (Figure 3 ) in the following ratios by weight: 1:1, 1:2, 1:3 (CGB:filler).

It is established that the dependence nature of CGB-based fine-grained concretes strength on water/binder value is similar to the nature of these dependencies on portland cement wherein slag sand-based concrete strength (in equally movable mixtures) is higher than on quartz sand.

Microanalysis of fine-grained concrete structure and element-by-element chemical analysis carried out on focused beam electronic microscope Teskan MIRA 3, showed (Figure 4) that the main crystal newgrowths are dihydrate gypsum, calcite, and low basic calcium hydrosilicates. 
Slag sand-based concrete's particles are combined with continued structure with strengthened connections between crystals (Figure 4a). Available pores are almost completely overgrown by newgrowths with fine-grained structure $(\leq 0.1 \mu \mathrm{m})$, presumably of NaAl silicates, hydroaluminosilicates, calcium hydroalumoferrites, and calcium sulphate dihydrate because of portland cement and calcined gypsum hardening. Formation of calcium hydrocarboaluminates containing in its formula $\mathrm{SO}_{3}$ type ions of $\mathrm{CaAl}_{2}\left(\mathrm{SO}_{3}\right)_{2}(\mathrm{OH})_{4} \cdot 6 \mathrm{H}_{2} \mathrm{O}$ is observed. In addition, increase of the contact surface between the crystal hydrate newgrowths is observed as well, which results in increased strength characteristics of the material.

a)

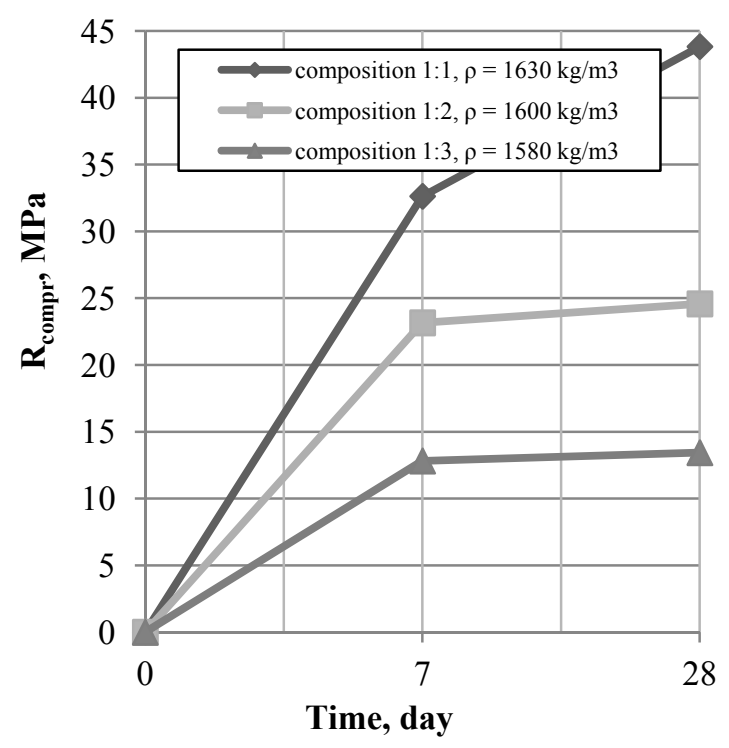

b)

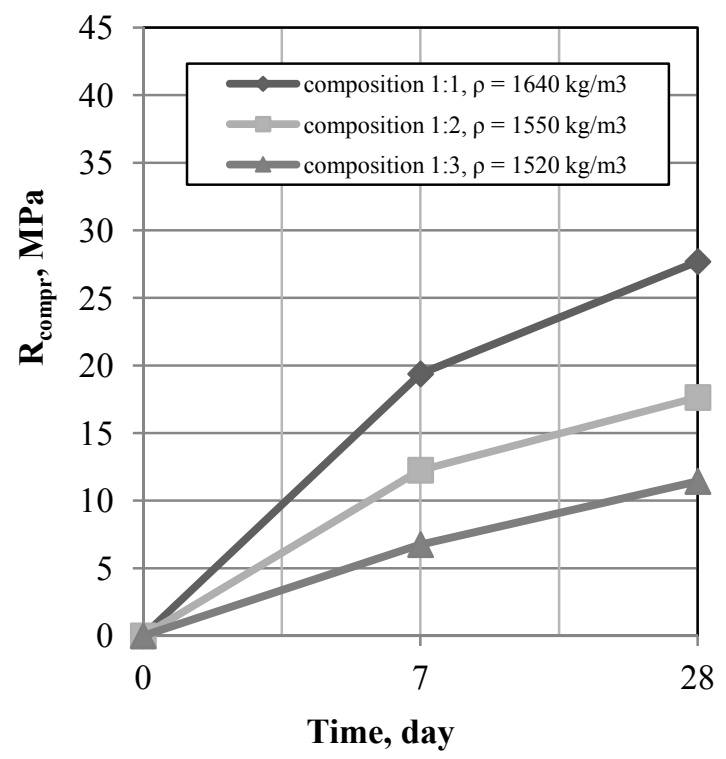


c)

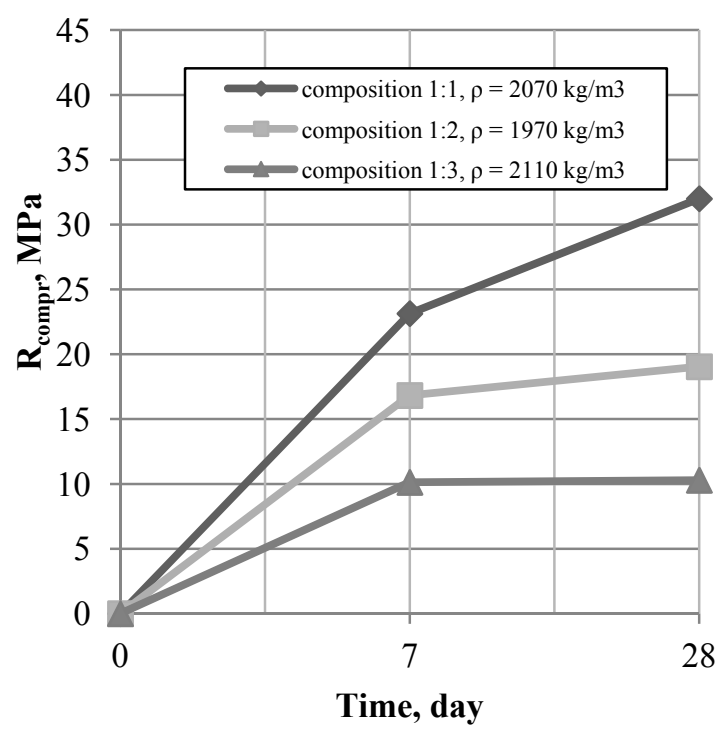

d)

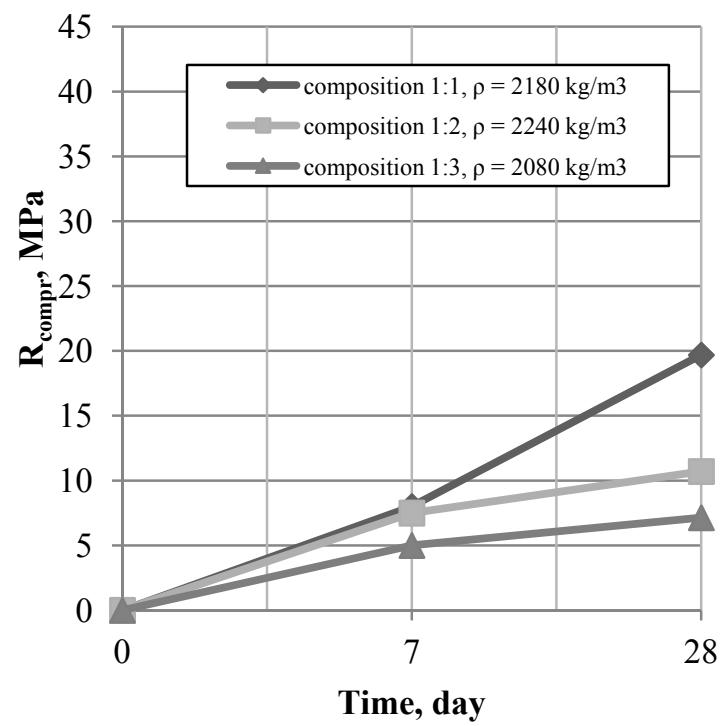

Figure 3. The properties of fine-grained concretes (FGC) based on CGB: a - FGC on slag sand with slag mineral additive; $\mathrm{b}$ - the same with flu ash mineral additive; $\mathrm{c}$ - FGC on quartz sand with slag mineral additive; $\mathrm{d}$ - the same with fly ash mineral additive

Loose structure with a significant amount of pores, as well as large and small pores between newgrowths' crystals form in concrete with quartz sand (Figure $4 b$ ).

Compacted (20MPa) concrete specimens with quartz sand have denser fine-grained structure with small pores between newgrowths' crystals (Figure 4c). Calcium hydrosilicates acquire morphology of dendroid formations, forming a compacted shell around gypsum particles.

Accumulation of insoluble newgrowths enables hydraulic (first in air and then in water) concrete hardening on CGB with ash or slag.

Full and qualitative evaluation of CGB-based concrete properties was made on research of their strength and deformation characteristics used in the calculation of structures - prism strength, elastic modulus, the Poisson ratio, and others (Table 4). 


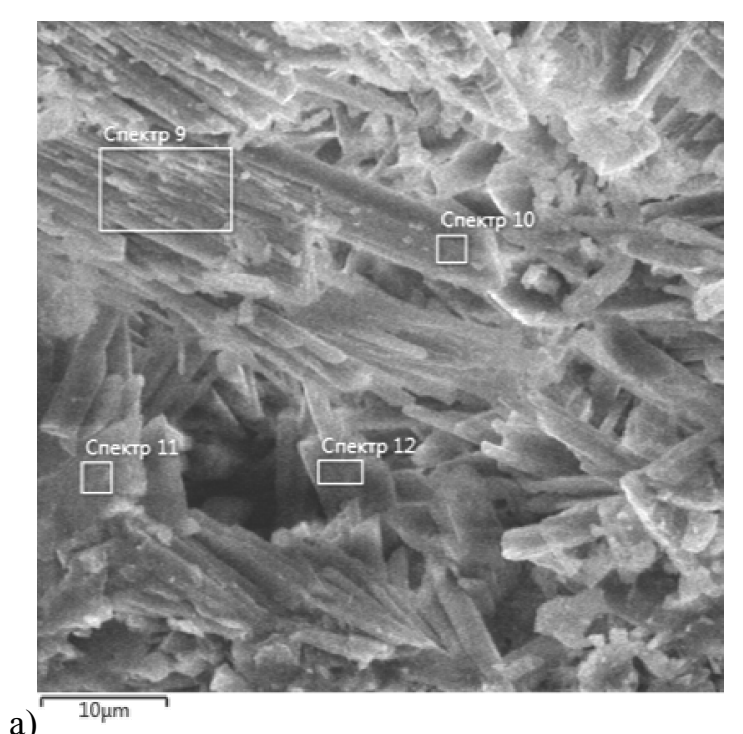

a)

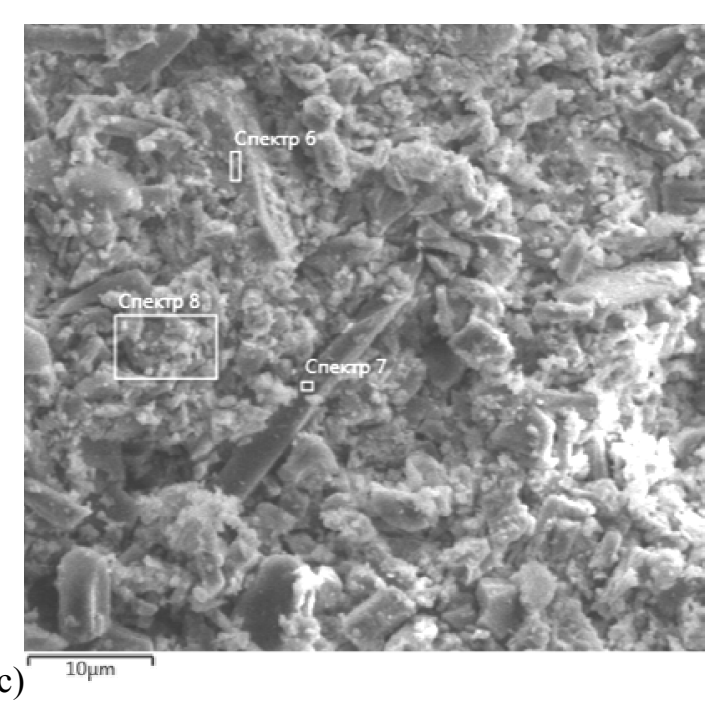

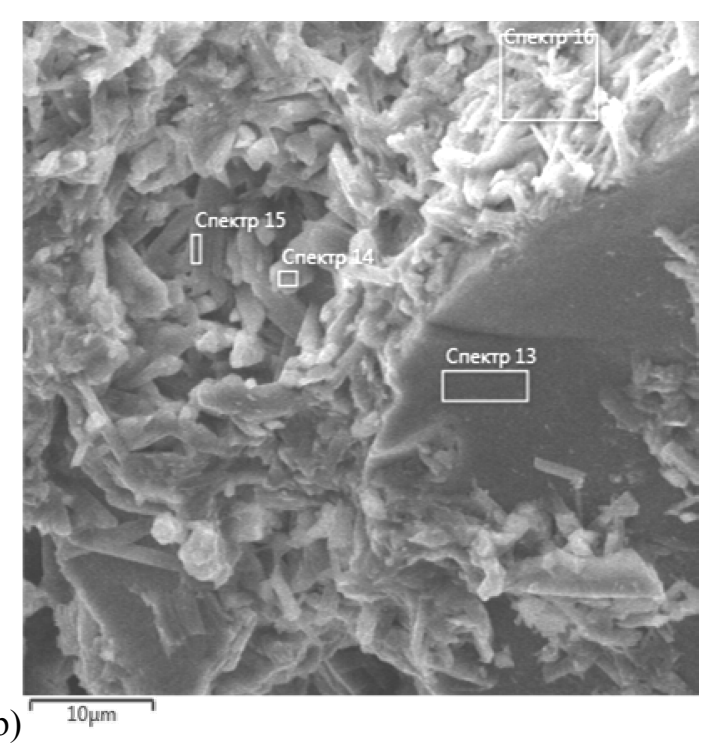

b)

Figure 4. Microphotographs of fine-grained concrete structures on CGB at the age of 1 year (5000 times magnification): a - concrete on slag sand (CGB with ash); $b$ - the same on quartz sand (CGB with ash); $\mathrm{c}$ - the same on quartz sand, extruded (CGB with slag)

In addition, indices of fine-grain concrete shrinkage strains are within the requirements of the regulations, swelling strains are growing rapidly during the first month and exceed shrinkage strains with subsequent stabilisation. For concretes of hard mixtures (CGB composition: slag $=1: 2$ ) after six months, they do not exceed $0.4 \mathrm{~mm} / \mathrm{m}$, and have a decaying nature; of movable mixtures $-0.5 \mathrm{~mm} / \mathrm{m}$.

It is found that over time the tensile strength of fine-grained concretes and softening coefficient increase slightly. Wall materials are obtained based on local raw materials found in Chechen Republic, including fabricated, of B15 class and above (depending on the composition and compaction method) and softening coefficient $0,66-0,73$.

Table 4. Strength and deformation properties of fine-grained concrete on CGB with fly ash in 28 days of age

\begin{tabular}{|c|c|c|c|c|c|c|c|c|c|}
\hline $\begin{array}{l}\mathrm{S} / \\
\mathrm{N}\end{array}$ & $\begin{array}{l}\text { Samples } \\
\text { designation }\end{array}$ & series & $\begin{array}{l}\text { Average } \\
\text { density, } \\
\mathrm{kg} / \mathrm{m}^{3}\end{array}$ & $\begin{array}{l}\text { Cube stren- } \\
\text { gth } \mathrm{R}_{\text {cube }} \\
\mathrm{MPa}\end{array}$ & $\begin{array}{l}\text { Prism } \\
\text { strength, } \\
\mathrm{R}_{\text {prism, }} \\
\text { MPa }\end{array}$ & $\begin{array}{l}\mathrm{R}_{\text {prism }} / \\
\mathrm{R}_{\text {cube }}\end{array}$ & $\begin{array}{l}\text { Elasticity } \\
\text { modulus, } \\
\mathrm{E}_{\mathrm{b}}, \mathrm{MPa}\end{array}$ & $\begin{array}{l}\text { The } \\
\text { Poisson } \\
\text { ratio }\end{array}$ & $\begin{array}{l}\text { Water } \\
\text { absorption, } \\
\% \text { weight }\end{array}$ \\
\hline 1 & Concrete & on & 1520 & 11.4 & 10.0 & 0.88 & 9230 & 0.23 & 3.6 \\
\hline
\end{tabular}


CGB with slag

sand

Concrete on

2 CGB with quart

sand

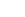

$\begin{array}{llllllll}\text { GB with quartz } & 2080 & 7.1 & 6.5 & 0.91 & 14000 & 0.32 & 1.8 \\ \end{array}$

Ability of fine-grained concrete (FGC) on CGB to hydraulic hardening was researched during 90 days in terms of their compression strength (Figure 5).

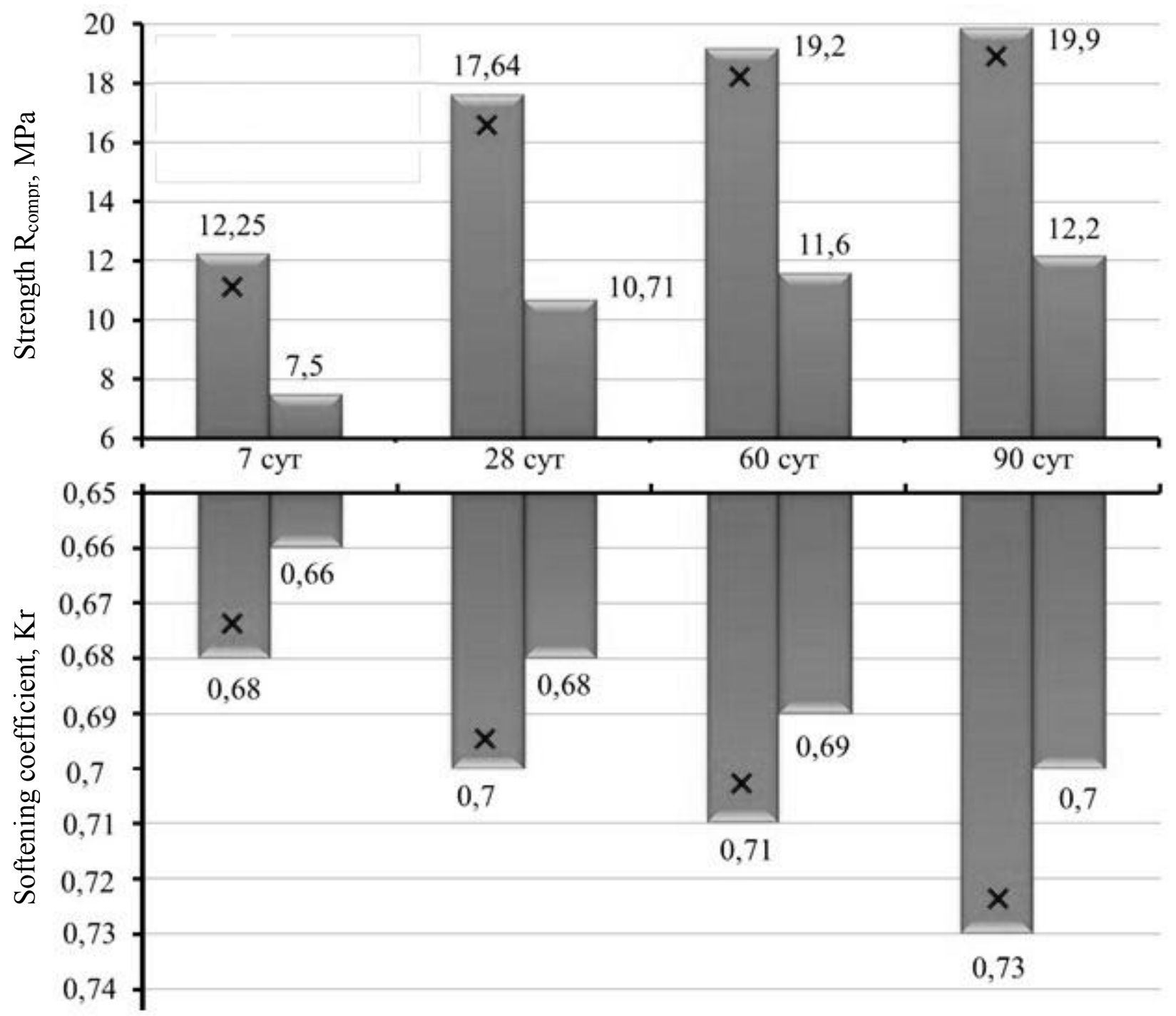

Figure 5. Dependence of the compressive strength and the softening coefficient of CGB-based FGC of age:

- FGC with fly ash and slag sand;

- FGC with fly ash and quartz sand

\section{Discussion and Conclusions}

CGB based on TPP bottom ash waste is promising for producing small piece wall materials in terms of environmental friendliness, ease of delivery, convenience in use due to small setting time, etc.

Research of siliceous components of fabricated materials influence nature on the processes of structure formation for the "gypsum - cement - bottom ash mineral additive - SP - water" system at hardening 
water-resistant CGB revealed that at the first stage, fast strength development of the system happens due to the synthesis of large crystals of gypsum dihydrate, simultaneously functioning as a regulating early setting. Then hydration of clinker minerals provides increased water resistance by creating poorly soluble newgrowths in previously created composite structure. Subsequent growth of performance characteristics is provided by newgrowths of $\mathrm{Ca}$ hydrosilicated 2nd generation due to the interaction of portlandite liberated during hydration of alite with X-ray amorphous particles of bottom ash mixture. Such CGB hydration mechanism minimizes internal stress and volumetric strain, and, therefore, reduces the number of microcracks, which leads to increased efficiency of the synthesized CGB compared with the traditionally used gypsum binders.

Research of the action mechanism of chemical additives (Polyplast SP-1 superplasticiser and citric acid) in CGB allows adjustment of rheological properties of mixtures and technical specification of concretes. At a dosage in an amount of $0.1-0.5 \%$ by weight of the binder, Polyplast SP-1 superplasticiser significantly increases the mobility of the mixture (from 0.12 to $0.22 \mathrm{~m}$ ). It was revealed that effective retarder of setting time is citric acid. At citric acid of $0.03-0.07 \%$, start of setting slows from 8-00 to 34-30 minutes. It is established that the developed complex chemical additive $(0.05 \%$ of citric acid $+0.3 \%$ of Polyplast SP- 1$)$ gives the possibility for adjusting the start of setting to 30 minutes and CGB hardening speed.

Thus, effectiveness of integrated use of fabricated materials in the production of fine-grain concretes from small piece wall materials is experimentally proven. Microstructure and morphology of fine-grain mineral additives of TPP slag and fly ash used as CGB fillers. Concrete compressive strength and concrete softening coefficient on CGB dependence on age is obtained, as well as, the influence of micro- and macrostructure of fine-grained concrete on CGB on performance offered-to-production fine-grained concrete for wall materials. Their strength and deformation characteristics are studied.

\section{References}

Alaskhanov, A. H., Murtazayev, S. A. Yu., \& Chernysheva, N. V. (2013). Using TPP bottom ash mixtures for composite gypsum binders. Ecology and Industry of Russia, 26-29.

Alhaj Hussein, M. (2010). Corrosion behaviour and durability of various cement and pozzolans. LAP LAMBERT Academic Publishing AG and Co.KG. 145.

Belov, V. V., \& Smirnov, M. A. (2009). Formation of optimal macrostructure construction mix. Building Materials, 9, 88-90.

Budnikov, P. P. (1951). Gypsum, its research and application. Gosstroyizdat, 418.

Burnett, W. C., \& Elzerman, A. W. (2001). Nuclide migration and the environmental radiochemistry of Florida phosphogypsum. Journal of Environmental Radioactivity, 54, 27-51. http://dx.doi.org/10.1016/S0265-931X(00)00164-8

Chernysheva, N. V., Kozeieva, E. V., \& Alaskhanov, A. H. (2011). Mineral additives from fabricated raw materials for the production of gypsum materials and products. Ecology: education, science, industry and health: materials of the International Scientific and Practical Conference, 15-18. Belgorod: BGTU Publishing House, 206-208.

Dvorkin, L. I., \& Dvorkin, O. L. (2007). Building materials from industry wastes. Rostov-on-Don: Feniks, 368.

Ferronskaya, A. V., \& Korovyakov, V. F. (1998). Operational properties of concrete on composite gypsum binder. Building Materials, 6, 11-13.

Ferronskaya, A. V., Korovyakov, V. F., \& Kaleiev, I. P. (1988). Improving quality of gypsum concrete by using chemical additives. In the book "Annotated list of scientific and technical development of Moscow universities, proposed for implementing in the practice of construction".

Gusev, B. V., Dementiev, V. M., \& Mirotvortsev, I. I. (1999). Norms of maximum allowable concentrations for housing building. Building materials, equipment, and technologies of XXI century, 5, 20-21.

Handbook. Gypsum materials and products (production and use). (2004). Under the general editorship by Professor D-r of Technical Sciences. Ferronskaya, A. V., Publishing House of Association of Building universities, 485.

Hanna, A. A., Abu-Ayana, Y. M., \& Ahmed, S. M. (2000). Phosphogypsum utilization - Part III: as adhesive filler and com posite materials. Journal of Materials Science and Technology, 16(4), 439.

Kazili u nas, A. (2007). Dehydration of Phosphogypsum and Neutralization of It's Impurities in the Steam of Raised Pressure. M. Ba c Auskien, Materials science (Medžiagotyra), 13(1), 57-59. 
Kolesnikova, I. V. (2002). Regulation of setting kinetics for gypsum plaster mixtures. Composite building materials. Theory and practice. Coll. of Scien. Works of Intern. Scientific and Technical Conf: Penza, 176-177.

Korovyakov, A. V. (2013). Modifying properties of gypsum binders by organo modifier. Dry construction mixes, 3, 15-17.

Korovyakov, A. V. (2013). Structure of hardening stone made of composite gypsum binders. Dry construction mixes, 1, 17-19.

Korovyakov, V. F. (2005). Improving water resistance of waterproof gypsum binders and expansion of application areas. Building materials, equipment, and technologies of XXI century, 3, 14-17.

Lesovik, V. S., Ageyeva, M. S., \& Ivanov, A. V. (2011). Granulated slags in production of composite binders. Bulleting of BGTU n.a. Shukhov, V. G., 3, 29-32.

Pereira, F. (2003). Production d'acide phosphorique par attaque de minéraux phosphates en utilisant $\mathrm{HCl}$ en tant qu'agent lixiviant, recuperation des terres rares comme sousproduits. PhD thesis, Ecole Nationale Supérieure des Mines de Saint-Etienne.

Perianez, R. (2005). Measuring and modeling temporal trends of $226 \mathrm{Ra}$ in waters of a Spanish estuary affected by the phosphate industry. Marine Environmental Research, 60, 453-456., http://dx.doi.org/10.1016/j.marenvres.2004.08.003

Shukla, V. K., Ramachandran, T. V., Chinnaesakki, S., Sartandel, S. J., \& Shanbhag, A. A. (2005). Radiological impact of utilization of phosphogypsum and fly ash in building construction in Indi. International Congress Series, 339-340. http://dx.doi.org/10.1016/j.ics.2004.10.024

Strokova, V. V., Zhernovskiy, I. V., Fomenko, Yu. V., \& Makarova, N. V. (2013). Regulation of fine grained concrete efflorescence process. Applied Mechanics and Materials, 357-360, 1300-1303.

Ursu, I. V., \& Dorozhkin, N. A. (2007). Resource-saving as a condition of providing ecological and economic security and socialization of the organization (enterprise) economy. Materials of Intern. scientific conf. "Scientific research, nanosystems and resource-saving technologies in the construction industry" (pp. 299-301). Belgorod.

Volzhenskiy, A. V. (1986). Mineral binders (4th ed.). Stroyizda, 431.

Wolicka, D. (2008). Biotransformation of phosphogypsum in wastewaters from the dairy industry. Polish $J$. Environ. Stud., 99(13), 5666-5672. http://dx.doi.org/10.1016/j.biortech.2007.10.029

\section{Copyrights}

Copyright for this article is retained by the author(s), with first publication rights granted to the journal.

This is an open-access article distributed under the terms and conditions of the Creative Commons Attribution license (http://creativecommons.org/licenses/by/3.0/). 